\title{
PHYTOCHEMICAL SCREENING AND IN VITRO ANTIOXIDANT ACTIVITIES OF LEAF EXTRACTS OF ALTERNANTHERA BRASILIANA (L). KUNTZE AND ALTERNANTHERA BETTZICKIANA REGEL.
}

\author{
KASTHURI $0 \mathrm{R}^{1 *}$, RAMESH $\mathrm{B}^{2}$ \\ ${ }^{1}$ Department of Biochemistry, Navarasam Arts and Science College for Women, Erode, Tamil Nadu, India. ${ }^{2}$ Department of Biochemistry, \\ PSG College of Arts and Science, Coimbatore, Tamil Nadu, India. Email: kasthure@gmail.com
}

Received: 05 February 2018, Revised and Accepted: 12 March 2018

\section{ABSTRACT}

Objectives: The present study was carried out to determine the phytochemical constituents and in vitro antioxidant activities of leaf extracts of Alternanthera brasiliana (L). Kuntze (A. brasiliana) and Alternanthera bettzickiana regel (A. bettzickiana).

Methods: Preliminary phytochemical screening was performed in petroleum ether, chloroform, acetone, ethanol, hydroethanolic and water extracts of leaves of A. brasiliana and A. bettzickiana. The level of alkaloids, flavonoids, total phenolic content, tannins, Vitamin C, Vitamin E, GSH, and total proteins were determined in hydroethanolic, ethanol, and water extracts. Antioxidant activity of the hydroethanolic leaf extracts of $A$. brasiliana and A. bettzickiana were determined by 2,2-diphenyl-1-picryl-hydrazyl-hydrate free radical scavenging assay, nitric oxide scavenging assay, superoxide anion scavenging assay, ferric reducing antioxidant power assay, total antioxidant capacity, and reducing power assay.

Results: The phytochemical screening of six different extracts of $A$. brasiliana and $A$. bettzickiana revealed the presence of various phytonutrients. Quantitative analysis of secondary metabolites in ethanol, hydroethanolic and water extracts of leaves of $A$. brasiliana and A. bettzickiana showed the presence of high amount of secondary metabolites in the hydroethanolic extract. In vitro, antioxidant assay of two plant extracts revealed that $A$. bettzickiana was more potent than A. brasiliana in scavenging free radicals.

Conclusion: The different extracts from A. brasiliana and A. bettzickiana and specifically the hydroethanolic extract of A. bettzickiana revealed several properties such as rich source of phytonutrients, higher free radical scavenging properties, and significant antioxidant capabilities. Therefore, the bioactive compound should be isolated in future studies and could be used as a safe and serve as a potential source of natural antioxidants.

Keywords: Alternanthera brasiliana, Alternanthera bettzickiana, Phytochemicals, Free radicals, Antioxidants.

(C) 2018 The Authors. Published by Innovare Academic Sciences Pvt Ltd. This is an open access article under the CC BY license (http://creativecommons. org/licenses/by/4. 0/) DOI: http://dx.doi.org/10.22159/ajpcr.2018.v11i6.25136

\section{INTRODUCTION}

Oxidative stress is the major causative factor in the induction of many chronic and degenerative diseases including atherosclerosis, ischemic heart disease, aging, diabetes mellitus, cancer, immunosuppression, neurodegenerative diseases, and others [1]. Free radicals are chemical species that contains one or more unpaired electrons. They are highly unstable and cause damage to other molecules by extracting electrons to attain stability [2]. Antioxidants are compounds that reduce oxidative stress in cells by neutralizing or scavenging reactive species by hydrogen donation [3]. Medicinal plants and their derivatives contain secondary metabolites which are potential sources of therapeutically effective medicines. Plant-based products are healthier, safer, and more reliable than synthetic products [4]. Commercially available synthetic antioxidants such as butylated hydroxyanisole and butylated hydroxytoluene are reported to be toxic to animals and human beings [5]. An alternative is the consumption of natural antioxidants from various food supplements and traditional medicines. Natural antioxidants which are ubiquitous in fruits, leaves, and flowers have been studied extensively as they are effective free radical scavengers and are presumed to be less toxic than synthetic antioxidants [6].

Alternanthera brasiliana and Alternanthera bettzickiana belonging to the family Amaranthaceae. This genus consists of approximately 80 species and is widespread genus with cosmopolitan distribution [7]. A. brasiliana is a herbaceous plant native to different countries such as Brazil, Australia, and India. It is commonly known in Brazil as Penicillin, Brazilian Joy Weed, grows easily on poor, and deforested soil [8]. A. bettzickiana Regel. is a species of flowering plant, known as red calico plant. The plant is used as an edible vegetable in Southeast Asia [9]. The present study was undertaken to assess the phytochemical constituents and antioxidant capabilities of edible herbs, A. brasiliana and A. bettzickiana

\section{METHODS}

Chemicals

All the chemicals used in this study were purchased from HIMEDIA Pvt. Ltd., Bombay. The chemicals used were of analytical grade.

\section{Collection of plant materials}

Fresh leaves of A. brasiliana and A. bettzickiana were collected from SKM Siddha and Ayurveda, Erode. The plant specimens were identified and authenticated by Dr. G.V.S. Murthy, Botanical Survey of India, Coimbatore, with voucher number BSI/SRC/5/23/2015/Tech/100 for A. brasiliana (L). Kuntze - AMARANTHACEAE and BSI/SRC/5/23/2015/ Tech/101 for A. bettzickiana (Regel) Voss - AMARANTHACEAE. The leaves of $A$. brasiliana and A. bettzickiana were separately shade dried and were coarsely powdered using a mechanical grinder.

\section{Extraction}

The shade dried coarsely powdered leaf samples of $250 \mathrm{~g}$ A. brasiliana and A. bettzickiana were extracted with solvents of increasing polarity such as petroleum ether, chloroform, acetone, ethanol, hydroethanolic, and water using hot continuous percolation process (Soxhlet) and the different extracts were concentrated using rotary vacuum evaporator (Buchi) at $50^{\circ} \mathrm{C}$, dried in a vacuum desiccator and stored at $-20^{\circ} \mathrm{C}$ till further use.

\section{Preliminary phytochemical screening}

The solvent extracts of leaves of $A$. brasiliana and A. bettzickiana were subjected to qualitative analysis to detect the presence of 
various phytoconstituents. They were screened for the presence of phytonutrients such as alkaloids, flavonoids, carbohydrates, amino acids and proteins, sterols and triterpenoids, tannins and phenolics, quinones, and saponins. The preliminary phytochemical analysis was performed using standard methods $[10,11]$.

\section{Quantitative phytochemical analysis}

Hydroethanolic, ethanol, and water extracts of leaves of A. brasiliana and $A$. bettzickiana were analyzed for quantitative estimation of alkaloids [12], flavonoids [13], total phenolics [14], tannins [15], and Vitamin C [16].

\section{In vitro antioxidant assays}

The hydroethanolic leaf extracts of $A$. brasiliana and A. bettzickiana were subjected to 2,2-diphenyl-1-picryl-hydrazyl-hydrate (DPPH) assay [17], nitric oxide (NO) scavenging assay [18], superoxide anion (SO) scavenging assay [19], ferric reducing antioxidant power (FRAP) assay [20], total antioxidant capacity (TAC) [21], and reducing power assay [22].

\section{Statistical analysis}

All the experiments were done in triplicates, and the results are expressed as mean \pm standard deviation.

\section{RESULTS AND DISCUSSION}

\section{Phytochemical screening}

Phytochemicals are bioactive, non-nutrient, naturally occurring compounds present in plants [23]. They usually occur as complex mixtures that differ among plant organs and stages of development [24]. The different solvent extracts of leaves of A. brasiliana and A. bettzickiana were evaluated for identification of efficient solvent system. The extracts were subjected to preliminary qualitative phytochemical investigations to determine phytoorganic constituents such as alkaloids, flavonoids, carbohydrates, amino acids and proteins, glycosides, sterols and triterpenoids, tannins and phenolics, quinones, and saponins. The results obtained are furnished in Table 1 for A. brasiliana and in Table 2 for A. bettzickiana.

Studies on the screening of the phytochemicals present in the tested six different extracts of $A$. brasiliana leaves revealed the presence of alkaloids, flavonoids, carbohydrates, amino acids and proteins, glycosides, sterols and triterpenoids, tannins and phenolics, and saponins in ethanol, hydroethanolic, and water extracts. Carbohydrates, sterols and triterpenoids, tannins and phenolics, and quinones were present in acetone extract. Petroleum ether and chloroform extracts showed the presence of sterols and triterpenoids, tannins, and phenolics.

Qualitative phytochemical screening of six different extracts of A. bettzickiana leaves revealed the presence of alkaloids, flavonoids, carbohydrates, amino acids and proteins, glycosides, sterols and triterpenoids, tannins and phenolic, quinones, and saponins in hydroethanolic and water extract. Ethanol extract contained all the phytonutrients present in hydroethanolic and water extract except sterols and triterpenoids and saponins. Acetone extract showed the presence of alkaloids, flavonoids, carbohydrates, amino acids and proteins, sterols and triterpenoids, and quinones. Alkaloids, carbohydrates, amino acids, and proteins were present in chloroform extract. Petroleum ether extract showed the presence of carbohydrates, amino acids and proteins, sterols and triterpenoids, tannins, and phenolics. Among the various solvent extracts studied in the leaves of A. brasiliana and A. bettzickiana, hydroethanolic followed by ethanol and water extracts were found to contain a maximum number of phytoconstituents. The phytochemical compounds detected in these plants were known to have medicinal importance. Tannins and flavonoids have been reported to possess biological activities that lead to prevention and management of many ailments [25]. Phenolics and flavonoids have been reported to be potent free radical scavengers [26]. Saponins have been found to have antimicrobial, anti-inflammatory, and hemolytic effects [27]. Terpenoids are known to be cytotoxic to tumor cells [28]. The presence of alkaloids, flavonoids, terpenoids, tannins, and phenolics in the leaf extracts of $A$. brasiliana and A. bettzickiana may preliminarily indicate their bioactivity, especially antitumor and antioxidant activity.

\section{Quantitative phytochemical analysis}

Medicinal plants are the rich source of alkaloids, phenolic acids, tannins, flavonoids, terpenoids, and other metabolites that act as primary antioxidants or free radical scavengers [29]. The quantitative phytochemical content of hydroethanolic, ethanol and water extracts of leaves A. brasiliana and A. bettzickiana were presented in Table 3.

Quantitative phytochemical analysis revealed that the hydroethanolic leaf extracts of $A$. brasiliana and $A$. bettzickiana retained a high amount of alkaloids, flavonoids, total phenolics, tannins, Vitamin C, Vitamin E, GSH, and total proteins. The ethanol and water extracts of $A$. brasiliana and $A$. bettzickiana leaves showed a lower amount of phytonutrients when compared to hydroethanolic extracts.

Alkaloids are the most efficient bioactive substances in plants [30]. Flavonoids and phenols are known to possess antioxidant activities. The presence of hydroxyl groups in their structures is responsible for antioxidant activity and their contribution to defense system against oxidative damage [31]. Antioxidants have the potential to exert their biological activity and scavenge reactive oxygen species (ROS) by quenching chain initiating catalysis, metal ion chelation, antioxidants, or by gene expression regulation [32]. Tannins are phenolic compounds, and plant phenolics are a major group of compounds that act as antioxidants or free radical scavengers [33]. Vitamin C is a powerful antioxidant because it can donate a hydrogen atom and form a relatively stable ascorbyl free radical. As a scavenger of ROS, ascorbate is shown to be effective against superoxide radical anion, hydrogen peroxide, hydroxyl radical, and singlet oxygen [34,35]. The nonenzymic antioxidant Vitamin E functions as peroxyl radical scavenger that terminates chain reactions [36]. GSH is a good scavenger of many free radicals such as $\mathrm{O}^{2-}, \mathrm{OH}$, and various lipid hydroperoxides and may help to detoxify many inhaled oxidizing air pollutants such as ozone, $\mathrm{NO}_{2}$, and free radicals.

The results obtained from the quantitative phytochemical analysis of hydroethanolic, ethanol and water extracts of $A$. brasiliana and A. bettzickiana revealed the presence high amount of phytochemicals in hydroethanolic extract followed by ethanol and water extracts. Therefore, they hydroethanolic extract of both plant materials was selected for the evaluation of free radical scavenging and in vitro antioxidant activity.

\section{Free radical scavenging potential and antioxidant properties DPPH assay}

The $\mathrm{DPPH}^{\bullet}$ is a stable free radical and is widely used to assess the radical scavenging activity of antioxidant compounds [37]. DPPH ${ }^{*}$ accepts an electron/hydrogen radical to become a stable diamagnetic molecule. Antioxidants on interaction with $\mathrm{DPPH}^{\bullet}$ transfer electron/ hydrogen atom to $\mathrm{DPPH}^{*}[38]$. A freshly prepared $\mathrm{DPPH}^{*}$ solution is of deep purple color with an absorption maximum at $517 \mathrm{~nm}$. In the presence of an antioxidant, this color disappears due to quenching of $\mathrm{DPPH}^{*}$ free radicals and converting them into a colorless product 2,2-dipenyl-1-picryl hydrazine [39]. In Table 4, DPPH radical scavenging activity of standard drug ascorbic acid and hydroethanolic leaf extracts of A. brasiliana and A. bettzickiana were shown.

At the minimum concentration of extracts used in this study (i.e., 50 $\mu \mathrm{g} / \mathrm{ml})$, the percentage inhibition caused by A. brasiliana and $A$. bettzickiana had activity values corresponding to $31 \pm 0.01$ and $35 \pm 0.02$, respectively. Whereas at the highest concentration (i.e., $350 \mu \mathrm{g} / \mathrm{ml}$ ), the activity values of $A$. brasiliana and $A$. bettzickiana were $66 \pm 0.01$ and $73 \pm 0.01$, respectively. It was observed that $A$. bettzickiana extract had the highest activity when compared to A. brasiliana. There was a 
Table 1: Qualitative phytochemical analysis of various solvent extracts of $A$. brasiliana leaves

\begin{tabular}{|c|c|c|c|c|c|c|}
\hline Phytochemical compound & Petroleum ether & Chloroform & Acetone & Ethanol & Hydroethanolic & Water \\
\hline \multicolumn{7}{|l|}{ Alkaloids } \\
\hline Dragendorff's & - & - & - & + & + & + \\
\hline Wagner's & - & - & - & + & + & + \\
\hline \multicolumn{7}{|l|}{ Flavonoids } \\
\hline Alkaline reagent & - & - & - & + & + & + \\
\hline Zinc test & - & - & - & + & + & + \\
\hline \multicolumn{7}{|l|}{ Carbohydrates } \\
\hline Molisch test & - & - & + & + & + & + \\
\hline Fehling's test & - & - & + & + & + & + \\
\hline Benedicts test & - & - & + & + & + & + \\
\hline \multicolumn{7}{|l|}{ Amino acids and proteins } \\
\hline biuret test & - & - & - & + & + & + \\
\hline Millon's test & - & - & - & + & + & + \\
\hline Ninhydrin test & - & - & - & + & + & + \\
\hline Glycosides & - & - & - & + & + & + \\
\hline \multicolumn{7}{|l|}{ Sterols and triterpenoids } \\
\hline $\begin{array}{l}\text { Liebermann-Burchard } \\
\text { test }\end{array}$ & + & + & + & + & - & - \\
\hline Salkowski's test & + & + & + & + & + & + \\
\hline \multicolumn{7}{|l|}{ Tannins and phenolics } \\
\hline Iodine test & + & + & + & + & + & + \\
\hline Nitric acid test & + & + & + & + & + & + \\
\hline Quininoes & - & - & + & + & + & - \\
\hline Saponins & - & - & - & + & + & + \\
\hline
\end{tabular}

+: Positive, -: Negative. A. brasiliana: Alternanthera brasiliana

Table 2: Qualitative phytochemical analysis of various solvent extracts of $A$. bettzickiana leaves

\begin{tabular}{|c|c|c|c|c|c|c|}
\hline Phytochemical compound & Petroleum ether & Chloroform & Acetone & Ethanol & Hydroethanolic & Water \\
\hline \multicolumn{7}{|l|}{ Alkaloids } \\
\hline Dragendorff's & - & - & - & + & + & + \\
\hline Wagner's & - & + & + & + & + & + \\
\hline \multicolumn{7}{|l|}{ Flavonoids } \\
\hline Alkaline reagent & - & - & + & + & + & + \\
\hline Zinc test & - & - & + & + & + & + \\
\hline \multicolumn{7}{|l|}{ Carbohydrates } \\
\hline Molisch test & + & + & + & + & + & + \\
\hline Fehling's test & + & + & + & + & + & + \\
\hline Benedicts test & + & + & + & + & + & + \\
\hline \multicolumn{7}{|l|}{ Amino acids and proteins } \\
\hline Biuret test & - & - & - & + & + & + \\
\hline Millon's test & - & - & - & + & + & + \\
\hline Ninhydrin test & + & + & + & + & + & + \\
\hline Glycosides & - & + & - & + & + & + \\
\hline \multicolumn{7}{|l|}{ Sterols and triterpenoids } \\
\hline $\begin{array}{l}\text { Liebermann-Burchard } \\
\text { test }\end{array}$ & + & - & + & - & + & + \\
\hline Salkowski's test & - & - & + & - & + & - \\
\hline \multicolumn{7}{|l|}{ Tannins and phenolics } \\
\hline Iodine test & - & - & - & + & + & - \\
\hline Nitric acid test & + & - & - & - & + & + \\
\hline Ferric chloride test & + & - & - & + & + & - \\
\hline Quininoes & - & - & + & + & + & + \\
\hline Saponins & - & - & - & - & + & + \\
\hline
\end{tabular}

+: Positive, -: Negative. A. bettzickiana: Alternanthera bettzickiana

dose-dependent increase in the percentage antioxidant activity for all concentrations tested. Ascorbic acid used as positive control showed scavenging activity with percentage inhibition of $81 \pm 0.02$ at the maximum concentration used. An effective antioxidant concentration required to decrease the early DPPH radical concentration by $50 \%$ is known as $\mathrm{IC}_{50}$, which was determined from scavenging activity plotted graph versus different concentrations of standard drug and extracts. Lower value of $\mathrm{IC}_{50}$ is a sign of strongest ability of extracts to act as potent DPPH radical scavengers. Highest $\mathrm{DPPH}^{\bullet}$ scavenging activity was of hydroethanolic extract of $A$. bettzickiana followed by A. brasiliana with $\mathrm{IC}_{50}$ values of 164.25 and $182.55 \mu \mathrm{g} / \mathrm{ml}$, respectively. The standard ascorbic acid showed an $\mathrm{IC}_{50}$ value of $78.05 \mu \mathrm{g} / \mathrm{ml}$. The DPPH radical scavenging abilities of the plant extracts showed proton-donating ability, and this could serve as free radical inhibitors or scavengers, acting possibly as primary antioxidants. Thus, the hydroethanolic extracts of the tested plants had strong ability to scavenge DPPH radical.

\section{NO scavenging assay}

NO is a free radical produced in mammalian cells, have a major role in the regulation of several physiological processes, including neurotransmission, vascular homeostasis, and antimicrobial and antitumor activities. Excess production of NO is linked with several diseases [40]. The extent of inhibition of NO radical generation 
Table 3: Quantitative phytochemical analysis of hydroethanolic, ethanol and water extracts of $A$. brasiliana and $A$. bettzickiana

\begin{tabular}{llll}
\hline Secondary metabolite & Extract & A. brasiliana & A. bettzickiana \\
\hline Alkaloids (\%) & Hydroethanolic & $11.4 \pm 1.20$ & $14.63 \pm 0.95$ \\
& Ethanol & $8.8 \pm 0.63$ & $11.7 \pm 0.60$ \\
Flavonoids (mg RU/g) & Water & $7.76 \pm 0.42$ & $9.7 \pm 0.56$ \\
& Hydroethanolic & $43.6 \pm 2$ & $60.5 \pm 1.53$ \\
& Ethanol & $38.2 \pm 1.53$ & $55.3 \pm 2$ \\
Total phenolics (mg GAE/g) & Water & $38.4 \pm 2$ & $40.4 \pm 1.53$ \\
& Hydroethanolic & $34.6 \pm 2.52$ & $47.3 \pm 0.58$ \\
Tannins (mg/g) & Ethanol & $31.7 \pm 2.65$ & $37.5 \pm 1.73$ \\
& Water & $28.3 \pm 2.52$ & $27.2 \pm 2.08$ \\
Vitamin C (mg/g) & Hydroethanolic & $81.1 \pm 1.73$ & $90.3 \pm 0.58$ \\
& Ethanol & $71.3 \pm 2.65$ & $82.7 \pm 2.31$ \\
Vitamin E (mg/g) & Water & $60.5 \pm 3.51$ & $72.9 \pm 1.73$ \\
& Hydroethanolic & $75.3 \pm 4.16$ & $85.5 \pm 4.16$ \\
GSH (mg/g) & Ethanol & $41.4 \pm 3.06$ & $53.6 \pm 2.52$ \\
& Water & $55.6 \pm 3.52$ & $72.2 \pm 2$ \\
Total proteins (mg/g) & Hydroethanolic & $35.9 \pm 0.58$ & $43.7 \pm 2.52$ \\
& Ethanol & $31.7 \pm 1.15$ & $36.9 \pm 1$ \\
& Water & $37.3 \pm 1$ & $28.5 \pm 2$ \\
& Hydroethanolic & $7.5 \pm 1$ & $11.2 \pm 1$ \\
\hline
\end{tabular}

RU: Rutin equivalent, GAE: Gallic acid equivalent. A. brasiliana: Alternanthera brasiliana, A. bettzickiana: Alternanthera bettzickiana

by the hydroethanolic extract from the leaves of A. brasiliana and A. bettzickiana was detected and compared with the standard ascorbic acid, and the results are shown in Table 5.

The results showed that the hydroethanolic extract of $A$. bettzickiana exhibited the maximum inhibition of $82 \%$ at a concentration of 350 $\mu \mathrm{g} / \mathrm{ml}$ when compared to A. brasiliana extract that showed somewhat lower inhibitory activity of $76 \%$ at the same concentration. The standard ascorbic acid showed maximum inhibition of $81 \%$. The NO scavenging ability of both plant extracts was found to be concentration dependent. Highest NO scavenging activity was exhibited by a hydroethanolic extract of $A$. bettzickiana with an $\mathrm{IC}_{50}$ value of $104 \mu \mathrm{g} / \mathrm{ml}$ followed by A. brasiliana with an $\mathrm{IC}_{50}$ value of $141.07 \mu \mathrm{g} / \mathrm{ml}$. The standard ascorbic acid exhibited an $\mathrm{IC}_{50}$ value of $20.64 \mu \mathrm{g} / \mathrm{ml}$. The scavenging activity of the extracts against NO was detected by its ability to inhibit the formation of nitrite through direct competition with oxygen and oxides of nitrogen in the reaction mixture [41]. Flavonoids and phenolic compounds may be possibly responsible for $\mathrm{NO}^{-}$scavenging activity [42].

In the present study, hydroethanolic leaf extracts of A. brasiliana and A. bettzickiana effectively scavenged NO radical, which competes with oxygen to react with NO and the formation of nitrite radical was inhibited.

\section{Superoxide radical scavenging assay}

Superoxide ion $\left(\mathrm{O}^{2-}\right)$ is an oxygen-centered free radical with one unpaired electron. It is a toxic product and formed as a byproduct of mitochondrial respiration, as well as several other enzymes, for example, xanthine oxidase and nicotinamide adenine dinucleotide phosphate oxidase enzyme [43]. Superoxide can be decomposed to form stronger oxidative species such as singlet oxygen and hydroxyl radicals. Superoxide ion is very harmful to the cellular components in a biological system [44]. Superoxide dismutase catalyzes neutralization of superoxide and protects against oxidative damage [45]. The decrease in absorbance at $560 \mathrm{~nm}$ with antioxidants indicated the consumption of SO in the reaction mixture. The extent of inhibition of superoxide radicals by hydroethanolic extracts of $A$. brasiliana and $A$. bettzickiana were analyzed using ascorbic acid as standard, and results are shown in Table 6.

The hydroethanolic extracts of $A$. brasiliana and A. bettzickiana exhibited potent scavenging activity for superoxide radicals in a
Table 4: DPPH radical scavenging activity of ascorbic acid, $A$. brasiliana and $A$. bettzickiana leaf extracts

\begin{tabular}{llll}
\hline Concentration $(\boldsymbol{\mu g} / \mathbf{m l})$ & \multicolumn{2}{l}{ Inhibition $(\%)$} \\
\cline { 2 - 4 } & $\begin{array}{l}\text { Ascorbic } \\
\text { acid }\end{array}$ & A. brasiliana & A. bettzickiana \\
\hline 50 & $47 \pm 0.57$ & $31 \pm 0.01$ & $35 \pm 0.02$ \\
100 & $53 \pm 0.00$ & $36 \pm 0.02$ & $40 \pm 0.00$ \\
150 & $58 \pm 0.00$ & $42 \pm 0.01$ & $49 \pm 0.01$ \\
200 & $63 \pm 0.00$ & $51 \pm 0.00$ & $58 \pm 0.02$ \\
250 & $68 \pm 0.00$ & $56 \pm 0.00$ & $62 \pm 0.01$ \\
300 & $73 \pm 0.01$ & $61 \pm 0.01$ & $66 \pm 0.01$ \\
350 & $81 \pm 0.02$ & $66 \pm 0.01$ & $73 \pm 0.01$ \\
\hline
\end{tabular}

*Mean \pm SD of three replicates. SD: Standard deviation, DPPH: 2,2-Diphenyl1-picryl-hydrazyl-hydrate, A. brasiliana: Alternanthera brasiliana, A. bettzickiana: Alternanthera bettzickiana

Table 5: NO scavenging activity of ascorbic acid, $A$. brasiliana and $A$. bettzickiana leaf extracts

Concentration $(\mu \mathrm{g} / \mathrm{ml}) \quad$ Inhibition (\%)

Ascorbic A. brasiliana A. bettzickiana acid

\begin{tabular}{llll}
\hline 50 & $53 \pm 0.02$ & $42 \pm 0.02$ & $45 \pm 0.01$ \\
100 & $59 \pm 0.05$ & $46 \pm 0.01$ & $49 \pm 0.00$ \\
150 & $67 \pm 0.04$ & $51 \pm 0.03$ & $55 \pm 0.02$ \\
200 & $74 \pm 0.01$ & $57 \pm 0.03$ & $61 \pm 0.01$ \\
250 & $79 \pm 0.02$ & $62 \pm 0.01$ & $68 \pm 0.01$ \\
300 & $85 \pm 0.02$ & $69 \pm 0.01$ & $75 \pm 0.03$ \\
350 & $81 \pm 0.02$ & $76 \pm 0.01$ & $82 \pm 0.02$ \\
\hline
\end{tabular}

*Mean \pm SD of three replicates. SD: Standard deviation, NO: Nitric oxide, A. brasiliana: Alternanthera brasiliana, A. bettzickiana: Alternanthera bettzickiana

concentration-dependent manner. The maximum scavenging activity was found at the highest concentration of $350 \mu \mathrm{g} / \mathrm{ml}$, in which A. bettzickiana showed more activity than A. brasiliana. Standard drug, ascorbic acid showed superoxide radical scavenging activity with $\mathrm{IC}_{50}$ value of $34.88 \mu \mathrm{g} / \mathrm{ml}$. A. bettzickiana showed more scavenging activity with $\mathrm{IC}_{50}$ value of $86.59 \mu \mathrm{g} / \mathrm{ml}$ followed by $A$. brasiliana with 
$124.46 \mu \mathrm{g} / \mathrm{ml}$. Plant phenols may exert protective effects by scavenging superoxide, which is implicated in tissue damage and accelerated inactivation of vasorelaxing NO [46]. Polyphenols and flavonoids are well-known scavengers of superoxide radical, hydroxyl radical, and hydrogen peroxide [47]. The remarkable quantity of phenols and flavonoids detected in the quantitative estimation of Alternanthera leaf extracts may be responsible for free radical neutralization especially in quenching superoxide radical, singlet, and triplet oxygen. These results pointed out that the hydroethanolic extracts of $A$. brasiliana and A. bettzickiana were potent scavengers of superoxide radicals.

\section{FRAP assay}

The ability of $A$. brasiliana and A. bettzickiana leaf extracts to reduce ferric ions was shown in Table 7.

Ferric reducing the antioxidant potential of $A$. brasiliana and A. bettzickiana extracts were estimated by their capability to reduce tripyridyl triazine (TPTZ)-Fe (III) complex to TPTZ-Fe (II). Considerable FRAP activity of standard and extracts as represented in Table 7 confirmed their reducing capacity. There was a concentrationdependent increase in the antioxidant activity of both plant extracts. At high concentration of $350 \mu \mathrm{g} / \mathrm{ml}$, A. brasiliana and A. bettzickiana extracts exhibited maximum activity. Antioxidants play an important role as reducing agent as they break the chains of free radicals by donating hydrogen atom [48]. The result of our study was comparable with the study of Benzie and Szeto [49] who found out that higher the phenolic content, higher would be the reducing power of the extract and these two have the strong correlation with each other. Rice-Evans et al. [50] stated that the phenolic compounds have the redox potential, hence, have the reducing properties, and can donate hydrogen atom as well as quench the singlet oxygen.

TAC

The total antioxidant activity of leaf extract was measured to evaluate both water-soluble and fat-soluble antioxidants totally. The principle of this assay involves the activity of an antioxidant compound that leads to a reduction of the hexavalent form of molybdenum [Mo (VI)] to the pentavalent form [Mo (V)] and the formation of a green phosphate/ Mo (V) complex at acidic $\mathrm{pH}$ and at a higher temperature. This is spectrophotometrically measured at $695 \mathrm{~nm}$. The intensity of green phosphomolybdenum complex gives the measure of total antioxidants present in the sample [51]. The results of total antioxidant activity in the hydroethanolic leaf extracts of $A$. brasiliana and $A$. bettzickiana are presented in Table 8.

The leaf extract of $A$. bettzickiana exhibited higher $(191 \mathrm{mg} / \mathrm{g})$ total antioxidant activity than $A$. brasiliana $(179 \mathrm{mg} / \mathrm{g})$. In both leaf extracts, there was a dose-dependent increase in total antioxidant activity. Many flavonoids and related polyphenols contribute significantly to the phosphomolybdate scavenging activity of medicinal plants $[52,53]$. The present study was in agreement with the above findings and indicated that the presence of significant levels of non-enzymic antioxidants, namely, flavonoids and polyphenols in leaf extracts of Alternanthera plants might contribute to the phosphomolybdate scavenging activity which was measured as TAC.

\section{Reducing power assay}

Reducing power assay served as a significant reflection of the antioxidant activity [54]. Reducing power is evaluated by the transformation of $\mathrm{Fe}^{3+}$ to $\mathrm{Fe}^{2+}$ in the presence of the extract that possesses reducing property [55]. Reducing the power of standard ascorbic acid, A. brasiliana and A. bettzickiana extracts were shown in Table 9.

The reducing power of both leaf extracts was found to be concentration dependent. The maximum reducing power was found at the highest concentration $(350 \mu \mathrm{g} / \mathrm{ml})$ in which $A$. bettzickiana showed more activity than A. brasiliana. Compounds with reducing power indicated
Table 6: Superoxide radical scavenging activity of ascorbic acid, A. brasiliana and $A$. bettzickiana leaf extracts

\begin{tabular}{llll}
\hline Concentration $(\mu \mathrm{g} / \mathrm{ml})$ & \multicolumn{3}{l}{ Inhibition $(\%)$} \\
\cline { 2 - 4 } & $\begin{array}{l}\text { Ascorbic } \\
\text { acid }\end{array}$ & A. brasiliana & A. bettzickiana \\
& $52 \pm 0.02$ & $41 \pm 0.02$ & $44 \pm 0.01$ \\
\hline 50 & $56 \pm 0.03$ & $48 \pm 0.02$ & $51 \pm 0.02$ \\
100 & $66 \pm 0.02$ & $53 \pm 0.01$ & $59 \pm 0.02$ \\
150 & $73 \pm 0.02$ & $64 \pm 0.01$ & $67 \pm 0.01$ \\
200 & $77 \pm 0.02$ & $69 \pm 0.00$ & $73 \pm 0.02$ \\
250 & $84 \pm 0.03$ & $73 \pm 0.02$ & $78 \pm 0.02$ \\
300 & $89 \pm 0.02$ & $79 \pm 0.02$ & $83 \pm 0.01$ \\
350 &
\end{tabular}

${ }^{*}$ Mean \pm SD of three replicates. SD: Standard deviation

Table 7: FRAP assay of ascorbic acid, $A$. brasiliana and A. bettzickiana leaf extracts

\begin{tabular}{llll}
\hline Concentration $(\mu \mathrm{g} / \mathrm{ml})$ & \multicolumn{3}{l}{ Optical density $(593 \mathrm{~nm})$} \\
\cline { 2 - 4 } & $\begin{array}{l}\text { Ascorbic } \\
\text { acid }\end{array}$ & A. brasiliana & A. bettzickiana \\
\hline 50 & $0.56 \pm 0.01$ & $0.31 \pm 0.01$ & $0.34 \pm 0.01$ \\
100 & $0.62 \pm 0.02$ & $0.39 \pm 0.02$ & $0.45 \pm 0.02$ \\
150 & $0.69 \pm 0.02$ & $051 \pm 0.00$ & $0.54 \pm 0.01$ \\
200 & $0.76 \pm 0.02$ & $0.59 \pm 0.01$ & $0.63 \pm 0.01$ \\
250 & $0.80 \pm 0.01$ & $0.63 \pm 0.00$ & $0.68 \pm 0.01$ \\
300 & $0.85 \pm 0.00$ & $0.73 \pm 0.03$ & $0.77 \pm 0.03$ \\
350 & $0.90 \pm 0.01$ & $0.81 \pm 0.02$ & $0.85 \pm 0.03$ \\
\hline
\end{tabular}

${ }^{*}$ Mean \pm SD of three replicates. SD: Standard deviation, FRAP: Ferric reducing antioxidant power, A. brasiliana: Alternanthera brasiliana, A. bettzickiana: Alternanthera bettzickiana

Table 8: TAC of $A$. brasiliana and $A$. bettzickiana leaf extracts

\begin{tabular}{lll}
\hline Concentration $(\mu \mathrm{g} / \mathrm{ml})$ & TAC & \\
\cline { 2 - 3 } & $\begin{array}{l}\text { (mg of ascorbic } \\
\text { acid/g of } \\
\text { A. brasiliana) }\end{array}$ & $\begin{array}{l}\text { (mg of ascorbic } \\
\text { acid/g of } \\
\text { A. bettzickiana) }\end{array}$ \\
\hline 50 & 18 & 21 \\
100 & 56 & 61 \\
150 & 95 & 101 \\
200 & 112 & 136 \\
250 & 179 & 191 \\
\hline
\end{tabular}

TAC: Total antioxidant capacity, A. brasiliana: Alternanthera brasiliana, A. bettzickiana: Alternanthera bettzickiana

Table 9: Reducing power of $A$. brasiliana and $A$. bettzickiana leaf extracts

\begin{tabular}{llll}
\hline $\begin{array}{l}\text { Concentration } \\
(\mu \mathrm{g} / \mathrm{ml})\end{array}$ & \multicolumn{3}{l}{ Absorbance at $\mathbf{7 0 0} \mathbf{~ n m}$} \\
\cline { 2 - 4 } & $\begin{array}{l}\text { Ascorbic } \\
\text { acid }\end{array}$ & A. brasiliana & A. bettzickiana \\
\hline 50 & $0.119 \pm 0.000$ & $0.107 \pm 0.000$ & $0.111 \pm 0.000$ \\
100 & $0.123 \pm 0.000$ & $0.113 \pm 0.001$ & $0.118 \pm 0.000$ \\
150 & $0.129 \pm 0.000$ & $0.117 \pm 0.002$ & $0.121 \pm 0.000$ \\
200 & $0.133 \pm 0.000$ & $0.122 \pm 0.002$ & $0.126 \pm 0.000$ \\
250 & $0.152 \pm 0.000$ & $0.137 \pm 0.001$ & $0.142 \pm 0.000$ \\
300 & $0.162 \pm 0.000$ & $0.148 \pm 0.002$ & $0.156 \pm 0.000$ \\
350 & $0.185 \pm 0.001$ & $0.160 \pm 0.002$ & $0.169 \pm 0.005$ \\
\hline
\end{tabular}

*Mean \pm SD of three replicates. SD: Standard deviation, A. brasiliana: Alternanthera brasiliana, A. bettzickiana: Alternanthera bettzickiana

that they are electron donors and can reduce the oxidized intermediates of lipid peroxidation processes so that they can act as primary and secondary antioxidants [56]. The antioxidants, present in the plant 
extracts reduce the ferric cyanide complex $\left(\mathrm{Fe}^{3+}\right)$ to ferrous cyanide and form $\mathrm{Fe}^{2+}$ [57]. The presence of higher amount of reductones in the hydroethanolic extract of $A$. brasiliana and A. bettzickiana that impart antioxidant action by donating a hydrogen atom may be responsible for the reducing ability.

\section{CONCLUSION}

The qualitative and quantitative phytochemical analysis of various extracts of leaves of A. brasiliana and A. bettzickiana revealed that hydroethanolic extract as a rich source of biologically important phytonutrients. Free radical scavenging and in vitro antioxidant studies showed better scavenging ability of hydroethanolic leaf extracts of A. bettzickiana than A. brasiliana. Both plants might be a good source of dietary antioxidants which play an important role in the prevention of diseases associated with oxidative stress. To increase the antioxidant potential of the plants, the pure active compound that has the ability to scavenge free radicals should be isolated and could be used in curing many oxidative stress-related diseases such as cancer, cardiovascular, and other chronic diseases.

\section{ACKNOWLEDGMENT}

The authors are thankful to the Management, PSG College of Arts and Science, Coimbatore, for providing with all the facilities required in this work.

\section{AUTHORS' CONTRIBUTIONS}

Mrs. Kasthuri OR contributed in performing the experiment, data compilation and wrote the first draft of the manuscript. Dr. Ramesh B involved in corrections in the manuscript and overall management of the study. Both authors read and approved the final manuscript.

\section{CONFLICT OF INTEREST}

The authors confirm that this article content has no conflict of interest.

\section{REFERENCES}

1. Young IS, Woodside JV. Antioxidants in health and disease. J Clin Pathol 2001;54:176-86.

2. Gulcin I. The antioxidant and radical scavenging activities of black pepper seeds. Int J Food Sci Nutr 2005;56:491-9.

3. Erkan N, Ayranci G, Ayranci E. Antioxidant activities of rosemary (Rosmarinus officinalis L.) extract, blackseed (Nigella sativa L.) essential oil, carnosic acid, rosmarinic acid and sesamol. Food Chem 2008;110:76-82.

4. Benli M, Bingol U, Greven F, Guney K, Yigit N. An investigation on to antimicrobial activity of some endemic plant species from Turkey. Afr J Biotechnol 2008; 7:-5.

5. Vinay RP, Prakash RP, Sushil SK. Antioxidant activity of some selected medicinal plants in western region of India. Adv Biol Res 2010;4:23-6.

6. Dakshayini PN, Basha PM. Phytochemical screening and in vitro antioxidant potential of tribulusterrestris fruit and Mesua ferrea flower extracts: A comparative study. Int J Pharm Pharm Sci 2018:10:70-5.

7. Zafra-Stone $\mathrm{S}$, Yasmin $\mathrm{T}$, Bagchi $\mathrm{M}$, Chatterjee $\mathrm{A}$, Vinson $\mathrm{J}$ A, Bagchi D. Berry anthocyanins as novel antioxidants in human health and disease prevention. Mol Nutr Food Res 2007;51:675-83.

8. Brochadoa CO, Almeidaa AP, Barretoa BP, Costaa LP, Ribeiroa LS, Peireira RL. Flavonol robinobiosides and rutinosides from Alternanthera brasiliana (Amaranthaceae) and their effects on lymphocyte proliferation in vitro. J Braz Chem Soc 2003;14:449-51.

9. Hundiwale JC, Patil AV, Kulkarni MV, Patil DA, Mali RG. A current update on phytopharmacology of genus Alternanthera. J Pharmacol Res 2012;5:1924-9.

10. Harborne JB. Phytochemical Methods-a Guide to Modern Techniques of Plant Analysis. $2^{\text {nd }}$ ed. London: Chapman and Hall; 1984. p. 4-16.

11. Trease G, Evans SM. Pharmacognosy. $15^{\text {th }}$ ed. London: Bailer Tindal; 2002. p. 23-67.

12. Obadoni BO, Ochuko PO. Phytochemical studies and comparative efficacy of the crude extracts of some homeostatic plants in Edo and delta states of Nigeria. Glob J Pure Appl Sci 2001;8:203-8.

13. Jia Z, Tang M, Wu J. The determination of flavonoid contents in mulberry and their scavenging effects on superoxide radicals. Food
Chem 1999;64:555-9.

14. Singleton VL, Orthofer R, Lamuela-Raventos RM. Analysis of total phenols and other oxidation substrates and antioxidants by means of folin-ciocalteu reagent. Methods Enzymol 1999;299:152-78.

15. Siddhuraju P, Manian S. The antioxidant activity and free radical scavenging capacity of dietary phenolic extracts from horse gram (Macrotyloma uniflorum (Lam.) Verdc.) seeds. Food Chem 2007; 105:950-8.

16. Klein BP, Perry AK. Ascorbic acid and vitamin A activity in selected vegetables from different geographical areas of the United States. J Food Sci 1982;47:941-5.

17. Brand-Williams W, Cuvelier ME, Berset C. Use of free radical method to evaluate antioxidant activity. Lebensm Wiss Technol 1995;28:25-30.

18. Sreejayan N, Rao MN. Nitric oxide scavenging by curcuminoids. J Pharm Pharmacol 1997:49:105-7.

19. Winterbourn CC, Hawkins RE, Brian M, Carrell RW. The estimation of red cell superoxide dismutase activity. J Lab Clin Med 1975;85:337-41.

20. Benzie IF, Strain JJ. The ferric reducing ability of plasma (FRAP) as a measure of antioxidant power: The FRAP assay. Anal Biochem 1996;239:70-6.

21. Prieto P, Pineda M, Aguilar M. Spectrophotometric quantitation of antioxidant capacity through the formation of a phosphomolybdenum complex: Specific application to the determination of vitamin E. Anal Biochem 1999;269:337-41

22. Oyaizu M. Studies on products of browning reaction: Antioxidative activity of product of browning reaction prepared from glucosamine. Japan J Nutr 1986;44:307-15.

23. Okarter N, Liu C, Sorrells ME, Liu RH. Phytochemical content and antioxidant activity of six diverse varieties of whole wheat. Food Chem 2009;119:249-57.

24. Wink M. Phytochemical diversity of secondary metabolites. J Encyclopedia Plant Crop Sci 2004;18:915-9.

25. James DB, Abu EA, Wurochekk AU, Orji GN. Phytochemical and antimicrobial investigation of the aqueous and methanolic extracts of Ximenia americana. J Med Sci 2007;7:284-8.

26. Asirvatham R, Christina AJ. Drosera indica L: Potential effect on liver enzyme, lipid profile and hormone change in dalton's lymphoma ascites (DLA) bearing mice. J Intercult Ethnopharmacol 2012;1:69-73.

27. Francis G, Kerem Z, Makkar HP, Becker K. The biological action of saponins in animal systems: A review. Br J Nutr 2002;88:587-605.

28. Batista R, Silva Ade J Jr., de Oliveira AB. Plant-derived antimalarial agents: New leads and efficient phytomedicines. Part II. Non-alkaloidal natural products. Molecules 2009;14:3037-72.

29. Sudhanshu, Nidhi R, Sandhya M, Vishal, Ekta M. Antioxidant agents alternative source for malaria disease. Int J Appl Pharm 2012;4:14-6.

30. Ahmad A, Husain A, Mujeeb M, Khan SA, Najmi AK, Siddique NA. A review on therapeutic potential of Nigella sativa: A miracle herb. Asian Pac J Trop Biomed 2013;3:337-52.

31. Saggu S, Sakeran MI, Zidan N, Tousson E, Mohan A, Rehman H, et al. Ameliorating effect of chicory (Chichorium intybus L.) fruit extract against 4-tert-octylphenol induced liver injury and oxidative stress in male rats. Food Chem Toxicol 2014;72:138-46.

32. Swargiary A, Nath P, Basumatary B, Brahma D. Phytochemical, antioxidant and trace element analysis of anthelmintic plants of northeast india. Int J Pharm Pharm Sci 2017;9:228-32.

33. Hollman PC. Evidence for health benefits of plant phenols: Local or systemic effects. J Sci Food Agric 2001;81:842-52

34. Rose RC. The ascorbate redox potential of tissues: A determinant or indicator of disease? News Physiol Sci 1989;4:190-5.

35. Weber P, Bendich A, Schalch W. Vitamin C and human health-a review of recent data relevant to human requirements. Int J Vitam and Nutr Res 1996;66:19-30.

36. Tappel AL. Vitamin E and selenium protection from in vivo lipid peroxidation. Ann N Y Acad Sci 1980;355:18-31.

37. Thambiraj J, Paulsamy S, Sevukaperumal R. Evaluation of in vitro antioxidant activity in the traditional medicinal shrub of western districts of Tamilnadu, India, Acalypha fruticosa Forssk. (Euphorbiaceae). Asian Pac J Trop Biomed 2012;2:S127-30.

38. Usmani S. Screening for antioxidant and free radical scavenging potential of extracts of leaves and flowers of Calotropis gigantea. Asian J Pharm Clin Res 2013;6:97-100.

39. Sumathy R, Sankaranarayanan S, Bama P, Ramachandran J, Vijayalakshmi M, Deecaraman M. Antioxidant and antihemolytic activity of flavonoids extract from fruit peel of Punica granatum. Asian J Pharm Clin Res 2013;6:211-4.

40. Hepsibha BT, Sathiya S, Babu CS, Premalakshmi V, Sekar T. In vitro studies of antioxidant and free radical scavenging activities of Azima 
tetracantha lam leaf extract. Indian J Sci Technol 2010;3:571-7.

41. Alasalvar C, Karamac M, Amarowicz R, Shahidi F. Antioxidant and antiradical activities in extracts of hazelnut kernel (Corylusavellana $\mathrm{L}$.) and hazelnut green leafy cover. J Agric Food Chem 2006;54:4826-32.

42. Chaulya NC, Haldar PK, Mukherjee A. In-vitro free radical scavenging activity of methanol extract of rhizome of Cyperus tegetum Roxb (Cyperaceae). Int J Curr Pharm Res 2010;2:39-43.

43. Muller FL, Lustgarten MS, Jang Y, Richardson A, Van Remmen H. Trends in oxidative aging theories. Free Radic Biol Med 2007:43:477- 503

44. Okhawa N, Ohishi K, Yagi H. Assay for lipid peroxides in animal tissues by thio-barbituric acid reaction. Anal Biochem 1979:95:351-8.

45. Basniwal PK, Suthar M, Rathore GS, Gupta R, Kumar V, Pareek A, et al. In vitro antioxidant activity of hot aqueous extract of Helicteres isora Linn. fruits. Nat Prod Radiance 2009;8:483-7.

46. Taubert D, Breitenbach T, Lazar A, Censarek P, Harlfinger S, Berkels R, et al. Reaction rate constants of superoxide scavenging by plant antioxidants. Free Radic Biol Med 2003;35:1599-607.

47. Jyothi SG, Chavan SC, Somashekaraiah BV. In vitro and in vivo antioxidant and antidiabetic efficacy of Cassia auriculata L. flowers. Glob J Pharmacol 2012;6:33-40.

48. Gordon M. The mechanism of antioxidant action in vitro. In: Food Antioxidants. Netherlands: Springer; 1990. p. 1-18

49. Benzie IF, Szeto YT. Total antioxidant capacity of teas by the ferric reducing/antioxidant power assay. J Agric Food Chem 1999;47:633-6.

50. Rice-Evans C, Miller N, Paganga GG. Antioxidant properties of phenolic compounds. Trends Plant Sci 1997;2:152-9.

51. Ashwini P, Krishnamoorthy M. Antioxidant activity of ethanolic extract of Cassia tora L. Int J Res Pharm 2011;2:250-2.

52. Sharififar F, Dehghn-Nudeh G, Mirtajaldini M. Major flavonoids with antioxidant activity from Teucrium polium L. Food Chem 2009;112:885-8.

53. Khan RA, Khan MR, Sahreen S, Ahmed M. Assessment of flavonoids contents and in vitro antioxidant activity of Launaea procumbens. Chem Cent J 2012;6:43

54. Oliveira I, Sousa A, Ferreira IC, Bento A, Estevinho L, Pereira JA, et al. Total phenols, antioxidant potential and antimicrobial activity of walnut (Juglans regia L.) green husks. Food Chem Toxicol 2008;46:2326-31.

55. Gulcin I, Oktay M, Kirecci E. Screening of antioxidant and antimicrobial activities of anise (Pimpinella anisum L.) seed extracts. Food Chem 2003;83:371-82.

56. Yen GC, Chen HY. Antioxidant activity of various tea extracts in relation to their antimutagenicity. J Agric Food Chem 1995;43:27-32.

57. Ferreira IC, Baptista P, Vilas-Boas MM, Barros LL. Free-radical scavenging capacity and reducing power of wild edible mushrooms from northeast Portugal: Individual cap and stipe activity. Food Chem 2007;100:1511-6. 